\title{
Structural design, typical damages and reinstatement of the Malakoff Towers
}

\author{
S. Niederhagemann \\ Deutsches Bergbau-Museum [DBM], Informationssysteme, Germany
}

\begin{abstract}
During the second half of the 19th century on continental Europe numerous masonry shaft buildings have been erected, which later, in referring to a fortress at Sevastopol in the Crimea, are called the Malakoff Towers. Due to a strong wish of a stately appearance, the design of these pit heads was oriented to the historistic style of the Anglo-Saxon castles. The carrying capacity of the towers was often so high that some of these structures remained over a hundred years in mining operation and are still preserved today.

The author is currently counselling the rehabilitation of three examples of this kind of former hoisting shaft structures in different states in the project. The following article engages with the question of the structural design and the typical damage symptoms of this type of industrial monuments. Among these the available determination methods and materials during the construction period is evident. Furthermore diverse workloads during the industrial use have caused typical damages. Depending on this realising opportunities for the structural repair are shown in practical examples.

Keywords: industrial heritage, rehabilitation.
\end{abstract}

\section{Introduction}

The Malakoff Towers of mining industry fascinated people for the past 150 years. None of these support structures is still in its original technical function. Nevertheless, some examples of this impressive industrial architecture are preserved. Where they are retained, they are witness of industrialization and identification object of the region and its industrial history. The following article considers with the specifics of this monuments and the possibilities for its preservation. 


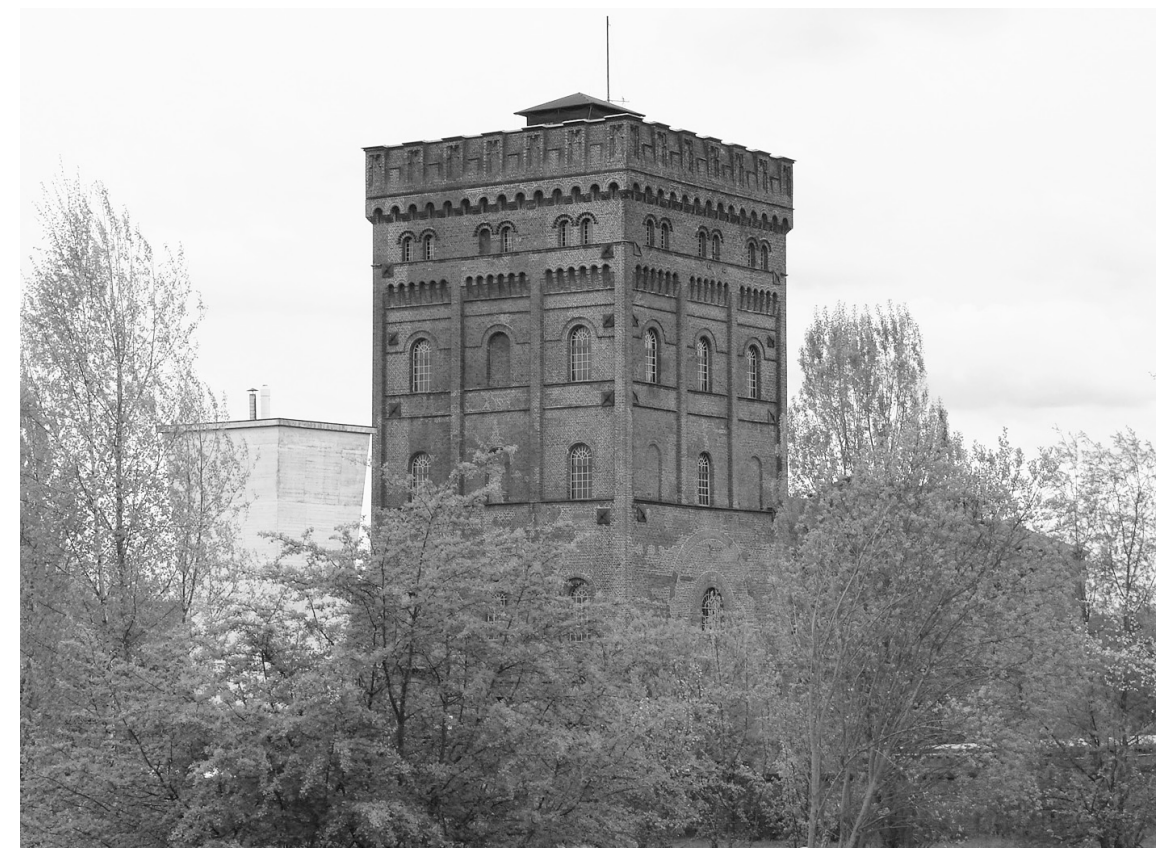

Figure 1: $\quad$ Malakoff Tower Hannover in Bochum Germany.

\section{Emergence}

During the industrialization on the continent the coal demand could not be met by opencast mining anymore. With the use of the steam engine for dewatering, it was possible to reach greater depths. The construction of a deep shaft is an eminent investment. The costs are rising with the diameter of the winding shaft. High depths also means long delivery times and therefore a reduced number of hoisting events. In order to transport sufficient material to the surface the mining cars where arranged in several floors one above the other [2]. Six to eight levels where common practice at that time. Thus it was necessary to place the pulleys, which direct the hoisting rope from the winding machine into the shaft, higher above the shaft in order get more space for security installations and serve the levels simultaneously.

A high position of the levels also simplified the separation processes. All these points made it necessary to build a high supporting, which could not be made in the common timber design. The confidence in the booming construction material of iron was still limited in the mining industry, despite the fact that many impressive bridges demonstrated the effectiveness of this material [3].

Besides the technical difficulties it was a major challenge to recruit workers. To attract people it was necessary to invest in the infrastructure. Beside the erection of mining plants the company builds housing, schools, hospitals and much more. For this purpose sometimes own brick factories were installed in 
order to secure the steady receipt of building materials. Therefore bricks were plentiful and economical affordable.

In the age of historicism numerous factories arose in the style of medieval castles. Also the Malakoff Towers are influenced by that style. The characteristic appearance of this massive industrial heritage is not paling its charm until today.

\section{Geographical extension}

Malakoff Tower plants are found mainly in the newly established mining plant of the second half of the 19th century in Central Europe. Most Malakoff plants are obtained in the Ruhr area [4] and the industrial zone of Saxony, Bohemia, Lower Silesia. But also in the neighboring mining districts a few isolated plants can be seen [5]. Most of the preserved plants are former coal mines. But there are also examples from various ore and even salt deposits.

\section{Structural design}

During more than hundred years of operation time the Malakoff towers often received a range of massive interventions in the load and the building structure. In this way, constructors tried to respond onto changing requirements of machine loads or compensate damages.

The wall footing is realized as a massive masonry strip foundation. These are slightly wider than the masonry and brought down up to two meters into the frostproof ground.

All Malakoff Towers have a square shape. The tower-like buildings consists of four interlinked walls. In most cases, the thickness of the masonry is reduced towards the top. The Malakoff Tower Prosper II in Bottrop for example has a thickness of $1,80 \mathrm{~m}$ at its foot and less than $30 \mathrm{~cm}$ at its top. Massive iron tie bolts reinforce the masonry. They are often installed completely visible.

\section{Loads}

Malakoff Towers are buildings of a considerable height. With a height of more than $30 \mathrm{~m}$ significant wind loads have to be expected. Because of the flat roofs the liftoff of the roof structure has to be prevented. Also the crenellations are often damaged by the high wind loads.

Due to massive construction the Malakoff Towers have a substantial weight. This makes them robust to many forces. On the other hand tilting can cause high forces.

The Malakoff Towers have once carried huge hoisting loads. These loads are not present anymore. For this reason, Malakoff Towers, in an undamaged state, can carry enormous loads, which allow many forms of new uses. 


\section{Typical damages}

\subsection{Tie bolts}

The most frequent form of damage is occurs because of the fact that the tie bolts lost their function. Because of the failure of individual support elements the whole installation becomes inefficacious. The results are vertical cracks in the lower tower areas, which are attributed to the high pressure loads from the weight of the massive walls.

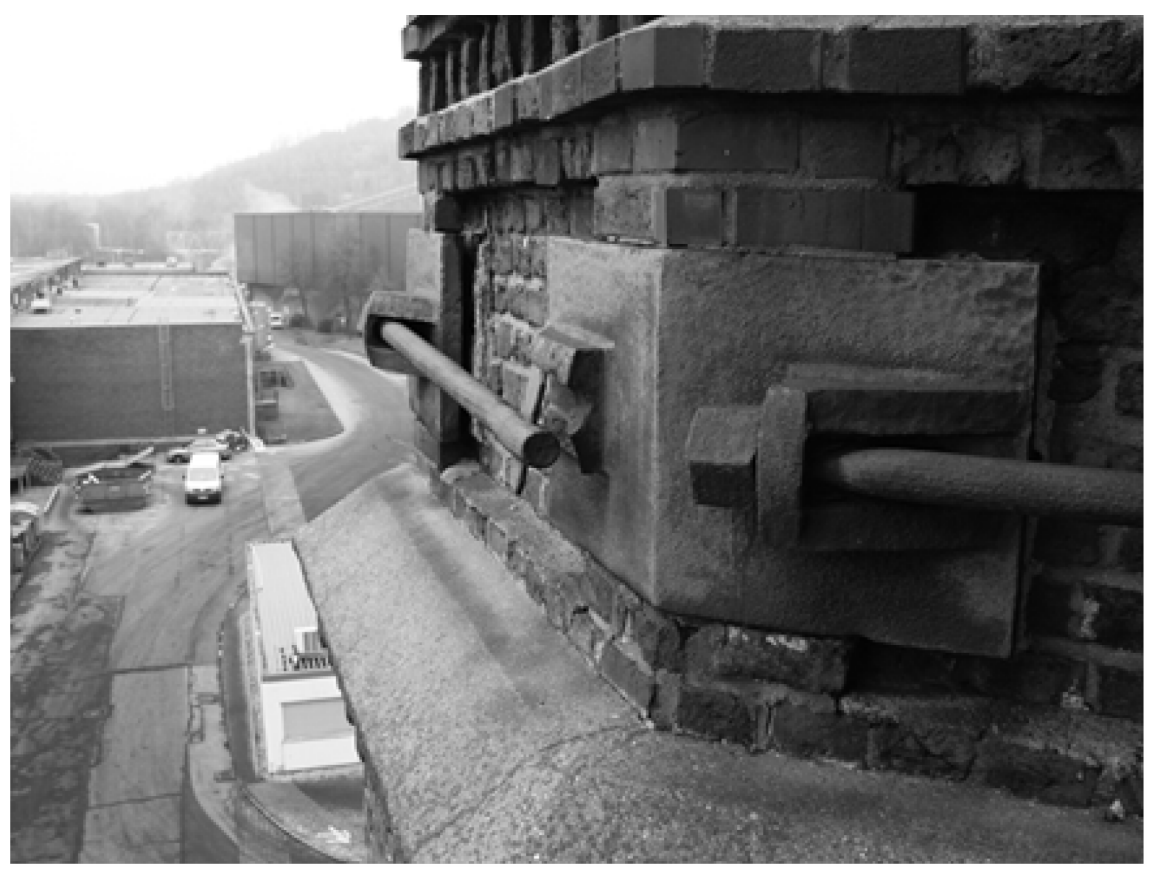

Figure 2: $\quad$ Broken tie.

\subsection{Subsidence}

Because the headgears are of course standing in mining areas, it seems likely that the structures could suffer mining subsidence. This damage was particularly avoided by defining an area where excavation is forbidden in order to protect the plant and the working processes above the surface. This prohibited area is called the safety pillar.

\subsection{Partial demolition}

With the closure of the plants the adjacent buildings, if they were not declared as a national monument, are often dismantled. Furthermore rotten components are removed without replacement. The results are openings in the building where weather, plants and animals can invade and damage the masonry. 

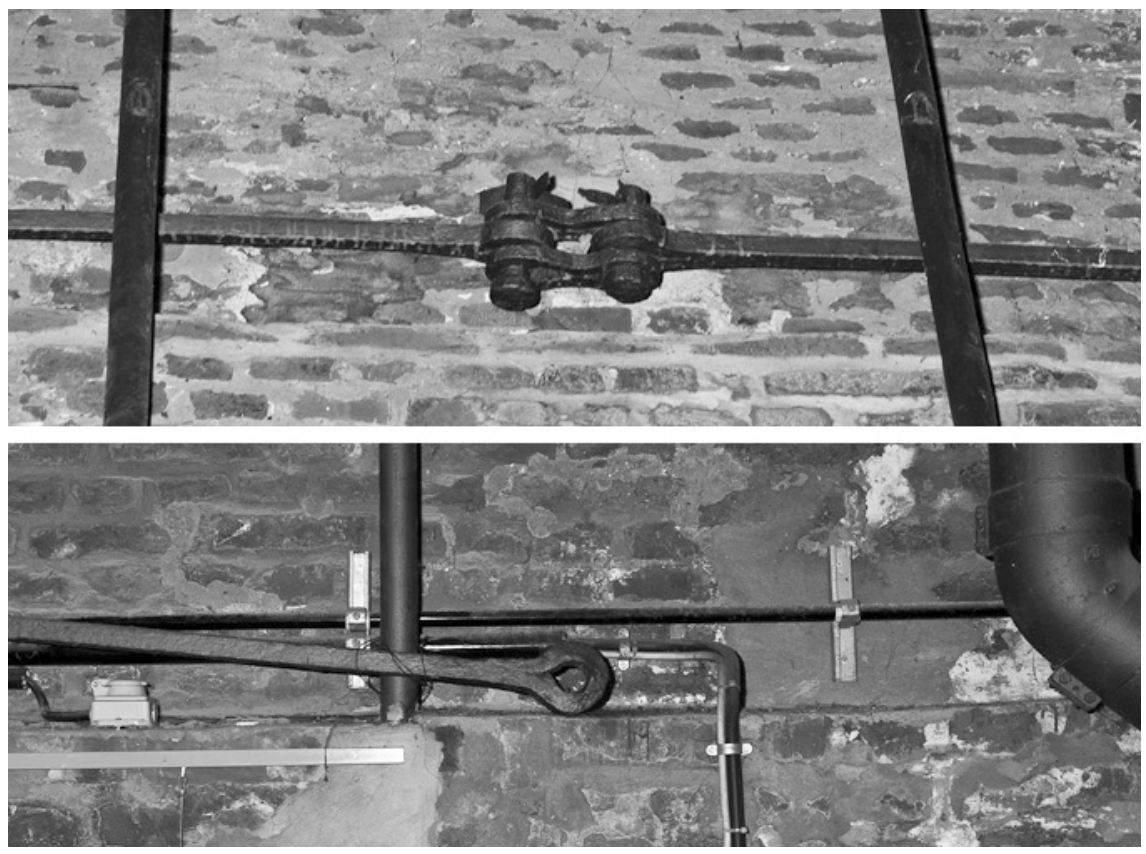

Figure 3: $\quad$ Tie at the original state and on the opposite side.

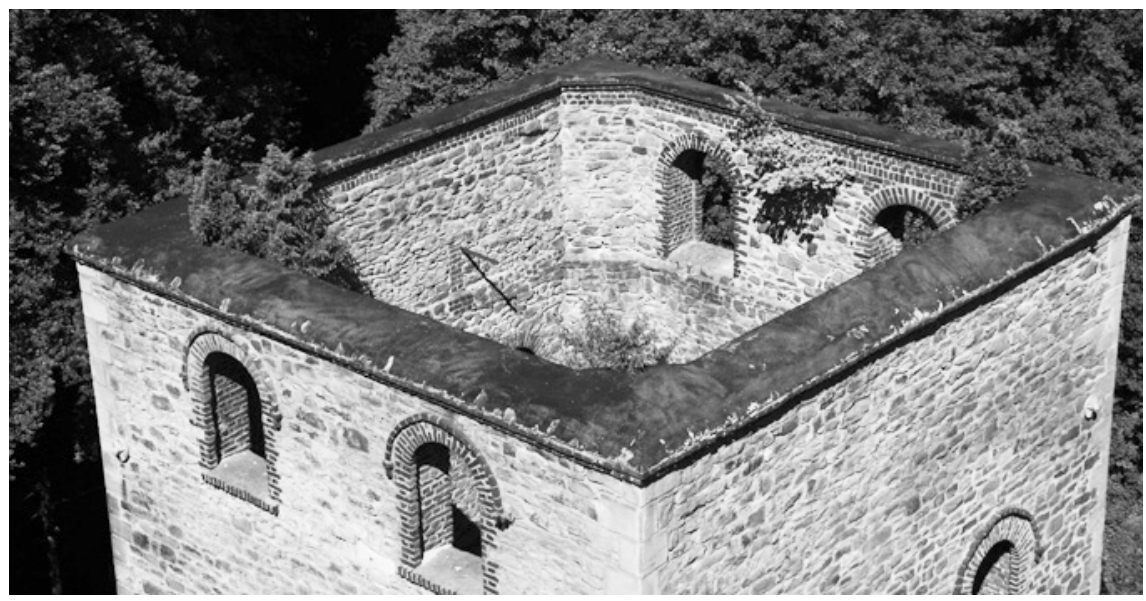

Figure 4: $\quad$ Missing roof and vegetation of Brockhauser Tiefbau (picture by Hensing/Knappenverein Schlägel u. Eisen).

Another problem is the commonly occurring demolition of stabilizing components. After decommission of the plants all still usable parts are recycled. For this purpose, machines and recyclable steel internals are used. Disassembly can lead to a destabilization of the overall structure. 


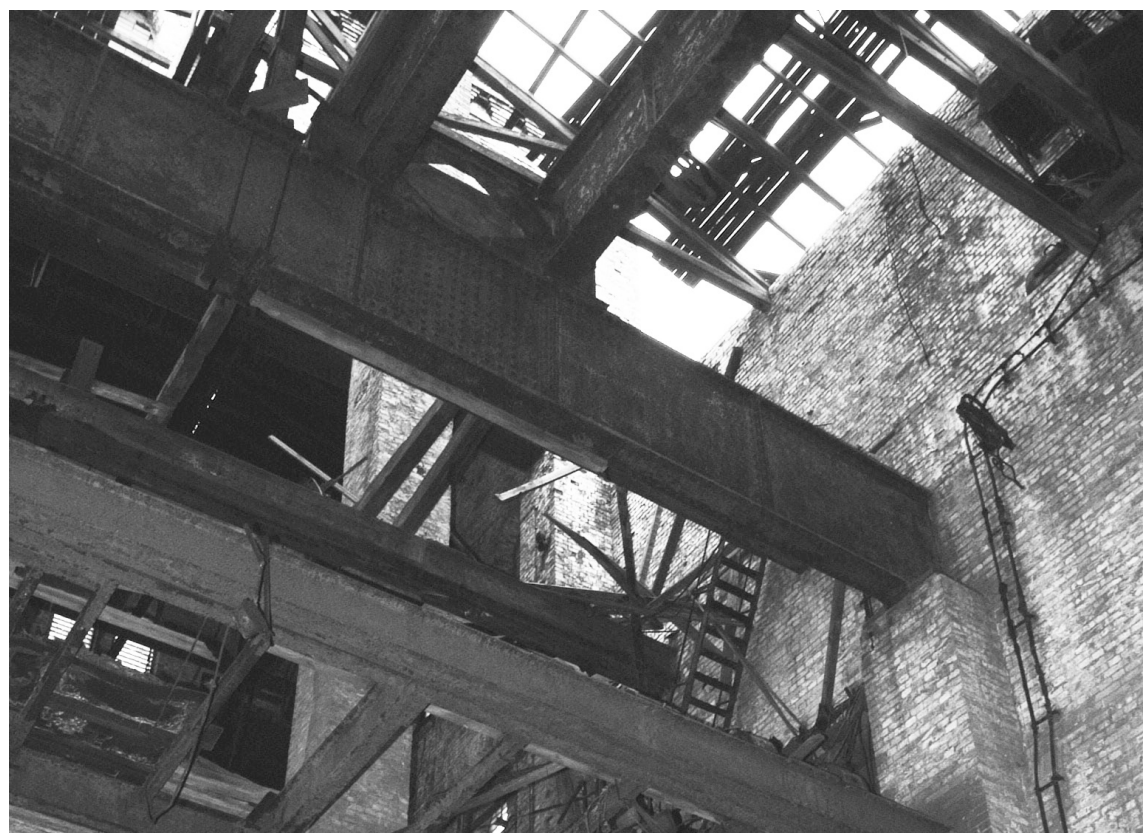

Figure 5: Partial demolition at Ernst Schacht IV.

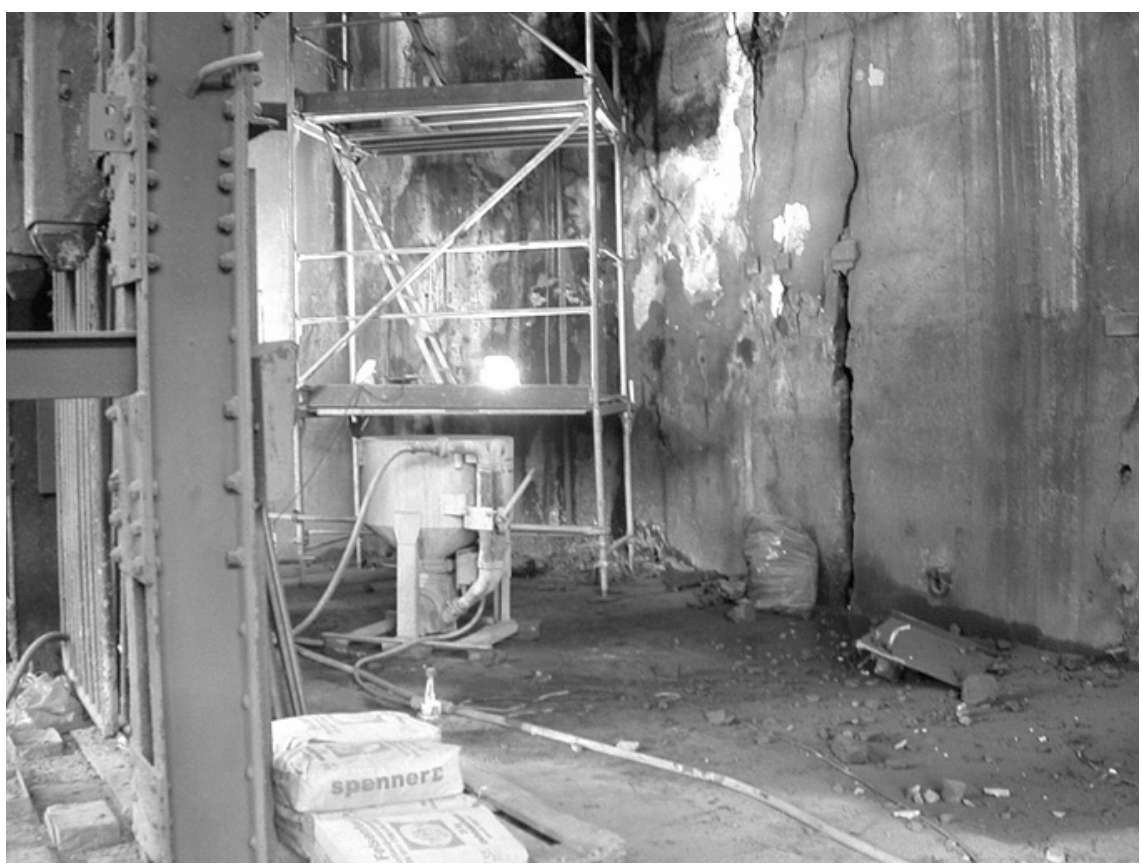

Figure 6: Needling and concrete injection at masonry cracks. 


\section{Overhaul}

If there are damages in the support structure, the static system has to be reviewed under consideration of the weakening. If necessary, substitute support structures have to be installed or the capacity of the original system has to be restored. For example cracked masonry can be repaired by needling and concrete injections [6].

Most of the new used Malakoff Towers are museums today. But there are also examples where a modification has taken place for an event location. The solid masonry allows the incorporation of massive installations and gives a comfortable indoor climate even without air conditioning.

\section{Conclusion}

The massive construction of Malakoff Towers assures them a long life if they are not removed intentionally. Nevertheless, the Malakoff Towers have not been without structural damage. Typical damage symptoms are a result of past vibrating winding loads and damaged tie bolts. Furthermore the constructions are often weakened by partial disassembly or modification of the structural system or the weather protection. If maintenance is wanted the Malakoff Towers can get a long-term use with a low budget restoration. The towers can be reused in varied ways.

\section{References}

[1] Slotta, R.: "Malakofftürme” in "Der Anschnitt” Ausg. 53, Vereinigung der Freunde von Kunst und Kultur im Bergbau e.V., Bochum, 2001.

[2] Schönberg, Heinrich: Die technische Entwicklung der Fördergerüste und türme des Bergbaus, in: Becher, Bernd; Becher, Hilla: Die Architektur der Förder- und Wassertürme, München 1971, S. 245-324, Zugl.: Aachen, Techn. Hochschule, Diss., 1970.

[3] Straub, Hans: Die Geschichte der Bauingenieurkunst, ein Überblick von der Antike bis in die Neuzeit, korrigierter Nachdruck der 4. Auflage, Basel 1996.

[4] Niederhagemann, Stefan; Tempel, Norbert: Malakofftürme im Ruhrgebiet eine Bestandsaufnahme, in LWL [editor] Industriekultur 3.12, 2012

[5] Guiollard, Pierre-Christian, les chevalements des houilleres francaises de 1830 à 1989, 1989.

[6] Niederhagemann, Stefan: Die Reaktivierung des Malakoffturmes Prosper 2 in Bottrop, in: Der Anschnitt, 5-6 2004. 